\title{
THE WORD, THE WORDS AND THE WITNESS: PROCLAMATION AS DIVINE AND HUMAN REALITY IN THE THEOLOGY OF KARL BARTH ${ }^{1}$
}

\author{
Trevor Hart
}

\section{Summary}

Karl Barth's entire theology is predicated upon the supposition that God has spoken to human beings. His exposition of the doctrine of the Word of God is informed both by trinitarian and incarnational analogies and insights. In each of the three forms of God's Word (Jesus of Nazareth, scripture, and Christian preaching) there is a paradox and scandal of identity between the divine and the human to be grasped. The relationships between these three, and the peculiar duality in unity which each manifests, are explored in this essay in relation to Barth's characteristic understanding of revelation as event.

\section{The Significance of Proclamation in Barth's Theology}

Karl Barth's entire theological project might legitimately be described as a 'theology of proclamation'. The assumption upon which it is predicated and with which Barth concerns himself as (he insists) the only legitimate starting point for truly theological activity, is the claim made by faith that God has spoken, that he has proclaimed his Word to humankind, that he has revealed himself.

As is well known, Barth sets himself from the outset firmly against all accounts of Christian knowledge of God which trace the proper basis of that knowledge to some inherent capacity for the divine, a sense of absolute dependence, experience of the ultimate or the numinous or whatever. Such accounts of the matter, he insists, cannot finally

${ }^{1} \mathrm{~A}$ revised form of the Tyndale Christian Doctrine Lecture, 1994. 
avoid capitulating to the accusation of Feuerbach that talk about God is in the end only talk about humanity. To seek to found talk about God, as much nineteenth century theology did, by pointing to the possibility and actuality of such anthropological phenomena was to invite the reduction of theological assertions to anthropological ones. It was to focus in the wrong place, to become preoccupied with the human organ of response rather than that objective reality which stimulates it. Christian talk about God is no more intended to be talk about a certain variety of religious or spiritual experience than talk about a glorious sunset is intended to be an indirect way of speaking about a complex chemical and physiological process taking place in our eyes, our optic nerves and our brain, or talk about the feel of polished wood an indirect way of speaking about the activity of the nerve endings in our fingers. Both levels of discourse may be appropriate. But our intention in speaking is to refer to the reality beyond the experience, that which provokes or evokes the experience, and not the experience itself.

God has turned to us in such a way that we can answer only with faith... We may not give this answer, but when we do it is an answer to God, an answer to this confidential turning and address of his. The address is not an expression of faith. Faith, if it is faith, finds its generative basis in it. ${ }^{2}$

Thus the proper basis of Christian talk about God, of knowledge of God, is precisely this unexpected and undeserved address of God, God's own proclamation to humanity, his speaking of the divine Word. And the proper form of all theological endeavour is that of response. Christian preachers, says Barth, dare to speak about God. But they can do so only on the presupposition that God himself has spoken first, that he has addressed humankind, has addressed them as human subjects, and that his address compels them also to speak. Otherwise their speech would be the ultimate presumption.

${ }^{2}$ Karl Barth, Göttingen Dogmatics Vol. I (henceforth GD I) (Edinburgh: T. \& T. Clark, 1991) 12. 
The point which Barth makes here is not concerned simply with the objective reference of theological statements, but, more strongly still, with the epistemic incapacity of humans in and of themselves to know or to speak of the particular object concerned, and the gracious initiative of God which alone bridges this gap by a supreme atoning and revelatory self-giving in the redemptive economy of the Son and Spirit together. Thus:

Only revelation in the strict sense overcomes the dilemma which haunts all religious philosophy, namely, that the object escapes or transcends the subject. Revelation means the knowledge of God through God and from God. It means that the object becomes the subject. It is not our own work if we receive God's address, if we know God in faith. It is God's work in us. ${ }^{3}$

When God reveals himself, furthermore, it is precisely in the form of Word, that is to say with attendant cognitive and linguistic form and content, and not via some mysterious and nebulous feeling or sense of ultimacy. In this event of revelation God himself is both the object of our knowing, and yet mysteriously the subject. He is the one who initiates and brings to completion the act of knowing by, on the one hand, positing himself objectively to be known, and on the other, entering into us as the Holy Spirit and creating the faith which responds appropriately to this self-manifestation. Thus (and it is vital that we bear this point in mind throughout what follows) the term revelation refers not to the objective self-manifestation alone, but equally to the act of faith in which it is heard and received and obeyed. Revelation for Barth, as Christina Baxter has put it,

...straddles objectivity and subjectivity, and is never completed or finished, for the relationship between God who is giving Himself to be known, and the 'human subject' who is receiving the capacity to know God is a continuing

${ }^{3} \mathrm{GD} I, 61$. 
relationship: it has to be 'new every morning' or it is not knowledge of God at all. ${ }^{4}$

That this happens, that God's Word is heard, rests, therefore, not in the realms of human capability or responsibility, but utterly with God in his sovereign freedom. But happen is precisely what it does. Revelation, the Word of God, is an event in which actual humans find themselves drawn into a circle of knowing in which they are given to share God's own knowledge of himself. As such it can in no way be abstracted from this happening and frozen or codified, any more than it can be provoked or coerced by human effort. As event or happening we can no more hold on to it or recreate it than we can cause it. We can only live in faith, recollecting that it has happened in the past, and trusting God's promise that it will happen in the future. We can even identify the places where it has happened and where we trust it will happen again. But we can no more confuse those places with the event itself than we would confuse an empty concert hall with the rapturous symphony which we heard performed there or the site of some long distant romantic encounter with the love which once infused it. To employ the word revelation to refer to any reality other than the dynamic happening itself is, for Barth, to confuse the issue, and to mistake purely human realities for that which is of God alone.

\section{The Threefold and Twofold Form of God's Self- Proclamation}

I want to turn now to consider the form which Barth understands the self-proclamation of God to have taken and to take. And I want to suggest that we can look at the matter through two specifically theological analogies, the relationship of which to the matter in hand is far from accidental-namely, the triunity of God as Father, Son and Holy Spirit, and secondly

${ }^{4}$ Christina Baxter, 'The Nature and Place of Scripture in the Church Dogmatics', in John Thompson (ed.), Theology Beyond Christendom (Allison Park: Pickwick Publications, 1986) 35. 
the hypostatic union of human nature and the reality of God himself in the person of the Son or Word in the incarnation. Both of these represent patterns or figures which Barth himself employs in discussing this matter even as early as the Göttingen Dogmatics of 1924.

For Barth the proclamation of God in which he speaks his Word to humans and reveals himself to them takes three basic forms which are yet mysteriously one Word. Each of these three forms, we should note, manifests a duality in unity, having both a fully human and a fully divine aspect, and united, more or less, by a radical becoming of God himself in which he takes on human form. The three forms are, of course, the man Jesus of Nazareth, the text of scripture, and Christian preaching.

The way in which Barth speaks of the relationships pertaining between these three are at once complex and highly ambiguous, or perhaps we should say rather dialectical. He seems to speak in different places, and sometimes even in the same places, in ways which entail contradiction and selfreferential incoherence. And yet when the substance of what he has to say is considered it becomes apparent that this same dialectical aspect is precisely parallel to that which is to be found in the theological speech of every age concerning the reality of Jesus Christ as the incarnate Son, and concerning the triune identity in distinction of God Father, Son, and Holy Spirit. My contention, then, would be that in order to grasp the logic of Barth's thought concerning God's proclamation it is most helpfully approached via these perichoretic and incarnational patterns, carefully distinguishing the sense in which these various realities are one from the sense in which they are yet three distinct realities, and equally carefully differentiating their human and their divine aspects.

There is, Barth affirms, an important distinction to be drawn between the realities to which we have referred. Thus the preacher must not confuse himself and his words with those of the apostles and prophets, which are the source of and the authority for his preaching. Likewise the human words of scripture are not to be confused with that historical selfmanifestation of God in the human history of Jesus to which it 
is their self-declared and unremitting responsibility to point and direct the church. Here, then, there is both difference and order to be perceived. If we think in terms of the order of our knowing, then it is with preaching that the church must begin. We hear the gospel expounded or proclaimed from the pulpit, or in some other context. Behind such preaching lies the given text of scripture with which the preacher must wrestle, and the meaning of which she must seek to unpack for her hearers. But the text is not, in this sense, the ultimate referent of her words. For there is another more ultimate authority to which scripture itself points, which lies beyond its words, and which engendered and called forth those words of witness in the first place. This other reality is, of course, the event in which God acted decisively for our salvation in the life, death and resurrection of his Son Jesus Christ. It is this which is the real object of our preaching. Thus the ontic order, the order of being, is the precise reverse of the noetic. It begins with Christ whose saving economy in due course calls forth scripture as a witness, and this in turn leads to the preaching ministry in the church. To fail to draw these careful distinctions and to maintain the relationships of order would be fatal for the church's life, for it might entail, for example, either an absolutizing of scripture as the ultimate referent of preaching (in which case it would become opaque, rather than serving as the transparent witness to the risen Christ which it is intended to be), or else a failure by the preacher to stand under the authority of the apostles and prophets (to confuse his words with theirs), and thence, rather than an absolutizing, a relativizing of the biblical text.

On the other hand, however, Barth insists that these three forms of existence (modes of being?) of the divine proclamation are yet one perichoretic reality, namely, the Word of God, incarnate as the man Jesus Christ, and, we might legitimately say, incarnate (albeit in a distinct manner) in both the text of scripture and the human verbiage of preaching. Viewed thus, he maintains, there can be no ascribing of a greater or lesser significance to any one over the others. Inasmuch as the same Word of God is present in each of the three there can be no question of making distinctions of value 
or importance, or of thinking of a gradual weakening or dilution of God's Word, thinking of the order of being as reflecting a hierarchy of power. For Barth Jesus Christ is God's Word, holy scripture is God's Word, and the preaching of the church is God's Word. God speaks in each of these three places, and we cannot discern any greater or lesser among them in this respect. How, then, are we to understand this? Is the preaching of the church really to be placed on the same level as the man Jesus? Are the words of Paul and Isaiah, let alone the words which Christian preachers utter on a Sunday morning, really of equal standing and revelatory significance with the personal presence of God among us in Jesus himself? And if so, how are we to hold on to what Barth has already said concerning the need for a strict ordering of authority between the three?

The answer, I want to suggest, lies in the need to draw a careful distinction between the humanity of the three forms and what we might legitimately term their divinity. Each of the three forms has a human aspect: the particular human story of Jesus; the texts which the church acknowledges as scripture; and the all too human words of the preacher. But in each case what must be recognised is that this human aspect as such, in and of itself, does not reveal God, but conceals him. There is nothing about this human being as such, nothing about these words as such, nothing about this preaching as such, which compels faith or reveals God in any straightforward or obvious manner. It is entirely possible for intelligent humans to see and hear these human realities and not to find themselves in the grip of a revelatory encounter. Every preacher, every Bible study group leader knows that. Those who followed Jesus around Palestine knew it. In order for these human realities to reveal God, therefore, they must, as it were, be accompanied by or infused with something more, with an activity of God which employs them as the instruments and agents of his selfrevealing activity. It is this and this alone which grants men and women the 'eyes to see and ears to hear' of which Jesus so often spoke. But this something, this presence of God is not to be confused with the human realities as such. The fathers of Chalcedon made that clear enough in the case of Jesus: in the incarnate union we have both fully human and fully divine 
reality in genuine union, but equally importantly, in genuine and continuing contradistinction. The humanity of Jesus does not become divine or even semi-divine. It comes to be the humanity of the Word. Likewise, for Barth, the words of scripture and those of the preacher do not cease to be fully human, but enter into a union with the Word of God who speaks through them.

To return, then, to the dialectic stated above, I think what Barth is saying is that if we think of the humanity of these three forms of the Word of God there is an immediate need to draw a threefold distinction, and to impose a clear order of importance and function. There is, firstly, an important distinction to be drawn between scripture and preaching. It has seemed good to God, Barth insists, to provide the church with an objective and abiding rule by which to measure its ongoing proclamation of God's Word, and this rule consists in the witness of scripture. As an historically constituted and literary phenomenon scripture has a permanence of form which enables it to stand identifiably over against and above the church, and thereby to act as an index or gauge of the church's faithfulness to the Word of God witnessed to within its pages. Thus scripture constitutes an authority for the preacher: it stands in the place of Jesus himself, since we have no direct access to him either in his historic or his risen form, except as these are mediated to us by the text of scripture. But an altogether more drastic distinction yet must be drawn which sets this first distinction in the shade. For between the humanity of Jesus Christ on the one hand, and the text and words of scripture and preaching on the other, there is an absolute distinction. Barth expresses it thus: The man Jesus is the revelation of God himself. In this divine speaking there is no other subject but God involved. Jesus is the reality of God's revelation in history. But scripture and preaching are not this reality as such. Considered as human realities they stand as witnesses to this revelation, and derive any meaning or authority which they have from their relationship to it. They are witnesses; Jesus is the one to whom they bear witness.

The point here is sharpened if we develop it in terms of the christological model. In Jesus Christ, God himself becomes 
a human person, identifies himself fully with this human life and history. Jesus' humanity, as the fathers put it, was anhypostatic, it had no prior or independent existence apart from the incarnation of the Son of God. Here then we have a simple and permanent relationship of personal identity between the Word and Jesus Christ. But it is not at all like this in the cases of scripture and preaching. Here what we have are human realities which do have a prior and independent human existence and which the Word of God 'becomes' in the sense that he enters into union with them in the event of revelation. But it is not a union of identity, but more one of indwelling, and it is not permanent but temporary. In christological terms, we might say, the sort of relationship between the humanity and divinity of scripture and preaching which Barth has in mind is more of a Nestorian union than a Chalcedonian one. This, it seems to me, is precisely why, when he is thinking of the human aspect of these things, Barth prefers the figure of John the Baptist to that of the humanity of Christ. John's role is to point away from himself to Christ and to bear witness to his hidden identity. Thus, I would contend, for Barth, scripture and preaching considered in their human aspect act precisely as witnesses to God's revelation in Jesus Christ. The differences between them, however significant, are purely functional. Both constitute human talk about God, human witness to him, and as such are set decisively over against 'revelation itself', namely, the reality of Jesus Christ in his human and divine aspects.

When, however, we consider the divine aspect of these three forms of God's proclamation, then we must confess that all of them constitute God's own address. The same revelatory event happens, whether it happens in and through the flesh of Jesus, the text of scripture or the words of the preacher. There are distinct modes of becoming involved: The flesh of Christ 'becomes' God's Word precisely because it is already God's Word, because the Word of God has become Jesus Christ; whereas the words of scripture and of the preacher become God's Word because this same Word which was in Jesus Christ enters into a moral and temporary rather than a hypostatic and permanent union with them, but a real and revelatory union 
nonetheless. Thus, Barth affirms, holy scripture is God's Word 'in exactly the same sense in which we have said this of the event of... proclamation', 5 namely that it becomes it through the miracle of God's willingness to become these words, to make his own Word known through them.

\section{The Scandal of Identity}

Grasping the nettle of the full humanity of the incarnate Word has always been the occasion for scandal and offence in the Christian church. This is so in christology, where there is the constant temptation to allow a subtle docetism to creep into our thinking about, for example, the limitations of Jesus' knowledge and understanding, or the genuine integrity and ferocity of his experiences of temptation. The same temptation arises in our understanding of scripture where, it seems, for many Christians an acknowledgement of the mundaneness, the contingency, the ordinariness and maybe even the weakness and folly of the texts as they have been transmitted to us, and viewed in their purely human aspect, is just too much to take. And so we have the emergence and popularity of doctrines of the infallibility and even inerrancy of the text as text which, it may be argued, seek successfully to avert the offence, but in doing so, it can hardly be denied, elevate the text even in its human aspect way above the level of anything recognisable as human textuality.

We do not, of course, on the whole, have quite the same problem with the third form of God's self-proclamation-i.e. human preaching. Why not? Perhaps we should? For what we are forced to reckon with here is an alleged Word of God which nonetheless is spoken through a human agency the limitedness, the weakness and certainly the sinfulness of which we are compelled to reckon with. We cannot deny it. If there is not a sense of offence or scandal here then I suspect that it is because we do not have a high enough view of the preacher's task, a high enough 'christology of preaching' as it were, to make our

${ }^{5}$ Karl Barth, Church Dogmatics (henceforth CD) Vol. I/1 (Edinburgh: T. \& T. Clark, 1975) 109. 
own weakness and sinfulness and base fleshliness as preachers a cause of offence and scandal.

In practice what we often do is to bracket off two forms of the Word of God-Jesus himself and holy Scripture-from the other-preaching-which we think of perhaps as in some sense less fully identifiable with God's own Word. If we do so then, doubtless unconsciously, we risk a betrayal of the Reformed heritage. For while the Reformers, with their socalled 'Scripture principle', firmly identified the human text of the biblical writers as the Word of God, Barth suggests, they no less surely identified the human words of the preacher with this same Word, and in the same sense. Thus, for example, the words of Bullinger in the 2nd Helvetic Confession: 'The preaching of the Word of God is the Word of God'.

It is this small word, this 'is' which, if we take it seriously, and if we face up to the full humanness of that to which it refers (the best and worst of Christian preaching), can only be the occasion of paradox, scandal and offence.

Barth, as we have seen, takes as his starting point this strong view of the identity of the text of scripture and the words of Christian preachers with God's own word. And for him there is a scandal, an offence not just in the case of preaching, but in the case of scripture also. For, as we saw in the previous section, if he will have us draw a line between these three forms of God's Word then it is not between Jesus and scripture on the one hand and preaching on the other. Rather, Jesus as himself the human form of God's personal (hypostatic) presence among us in history is decisively set apart from scripture and preaching, both of which are to be understood as witness to that same historical and supra -historical reality.

So too for Barth the scandal and offence of identity in the case of Scripture is not 'how can this divine reality be thought of or treated in the same basic categories as purely human realities?', but, as in the case of preaching, 'how can this weak, sinful and errant human reality be identified with God's Word?' Whereas all too often we seek to remove the cause of offence, either (in the case of Scripture) by qualifying the humanity of the text and pruning away those aspects which might make its assumption by God problematic, or (in the case 
of preaching) by weakening the 'is' and not taking fully seriously the identity of our human words with God's Word, Barth sees this as a false response which denies the scandal rather than faces up to and grasps it. Thus he both insists upon the full deity of scripture and preaching, and upon their full humanity, even to the point of conceding their sinfulness, a step which places him decisively beyond the christological analogy.

Thus we find once again a certain dialectical quality in what Barth has to say on this topic. On the one hand both scripture and preaching are to be likened to the humanity of the Logos which remains fully human in the event of incarnation and even in its glorified state. There is no mystical fusion or change whereby the humanity becomes something which, in and of itself, is possessed of revelatory power or glory. ${ }^{6}$ Considered humanly there is nothing about the logical form, the material content, the religious profundity or the personal power of any portion of Scripture or any preacher's discourse which could serve as such to reveal God. In both cases there are varying degrees of all these things. But, as the words of Isaiah are applied to the flesh of Jesus so they might well be applied to the 'flesh' of text and proclamation: 'he had no form or majesty that we should look at him, nothing in his appearance that we should desire him... as one from whom others hide their faces he was despised, and we held him of no account' ${ }^{\prime}$.

Barth goes further still. What we must say, he insists, is that in the case of scripture just as surely as in preaching 'fallible men speak the Word of God in fallible human words' 8 There is the scandal of identity in all its stark offence. Fallibility and God, we tend to suppose, don't mix-any more than passibility and God, ignorance and God, crucifixion and God. Yet for Barth in both scripture and preaching (and here as elsewhere as we have seen they stand and fall together-they are both human entities in the same sense and Word of God in the same sense) the two are clearly juxtaposed and, by that problematic

6See GD I. 271.

7Is. 53:2-3.

${ }^{8}$ CD I/2 (Edinburgh: T. \& T. Clark, 1956) 529. 
is, identified. Preaching is human talk about God (thus far we might agree) in and through which God speaks about himself, 9 and to which God commits himself absolutely 'in such a way that like the existence of Jesus Christ himself it is God's own proclamation'. 10 Here, then, is the other side of the dialectic. These human words, (of even the best of which, Barth insists, it remains true that, as Paul says 'all men are liars')11 are yet God's own words, words which he himself adopts and speaks. On the one hand we must ever distinguish the human from the divine, the Word which God speaks from the words which Paul speaks and which you or I speak. 'These', Barth affirms, 'are two different things' ${ }^{12}$ And yet on the other hand we must insist with equal vigour and in the strongest possible sense that 'they are not two different things but become one and the same thing in the event of the Word of God'.13 They are both; human witness to revelation, and the very Word of God, revelation itself. 14 There is both identity in difference, and difference in identity. But that there is identity at all is a source of scandal and offence.

In relation to scripture in particular Barth finds himself compelled to spell out this offence in the face of infallibilist and inerrantist views which, as he sees it, fail to face up to the offence by failing to face up to the scandalous humanity which the Word of God, as it were, assumes in this form of divine selfproclamation, and which seek to identify the revelatory capacity of scripture in some facet of the text as such-its literal propositional truth, its theological orthodoxy or whatever. This he considers tantamount to seeking Jesus' divinity at the level of his humanness, in his miracles, his teaching, his ethical example and so on. In reality, Barth insists, as a human entity scripture really is treatable like any other-although that includes taking genuine and full account of the historical intentions of the human authors as they understood their task under God. In

${ }^{9} \mathrm{CD} \mathrm{I} / 1,95$.

${ }^{10} \mathrm{CD} \mathrm{I} / 2,745-6$. My italics.

${ }^{11}$ Rom. 3:4; see CD I/2, 734.

${ }^{12} \mathrm{CD} \mathrm{I} / 1,113$.

${ }^{13}$ Ibid.

14See CD I/2, 473. 
one important sense, therefore, we certainly cannot treat it just like any other human text. To do so would be bad literary practice as well as bad theology. The Bible is not any other human text, but this particular text; and we must attend with integrity to the specificity of this text, its Sitz im Leben and Sitz im Denken, and the particular world of meaning which it therefore evokes. Nonetheless, to do this is precisely to recognise, as we can and must, that it is a human book, and that when we handle it, print it, translate it, edit it, read it and so on, we are handling a piece of human literature. Whatever else we may want to say about the Bible we must certainly say this much. And part of what that entails, Barth argues, is recognition of a genuinely human textuality with all its attendant weaknesses and problems.

Why does Barth insist that it is thus? One answer to that question might be that the advent of modern historical and critical methods as applied to the biblical text have made views of its infallibility and inerrancy impossible to sustain without a sacrificium intellectus, or else only by qualifying these to the point where they seem to have lost their basic intent. That case is one which must be faced seriously, and no doubt it played its part in shaping Barth's mind; for, whatever may sometimes be said about his attitude to biblical criticism, he was able to take its learning fully on board. He considered the way in which it had often been used to be an irrelevance for the task of Christian proclamation, but that is another matter altogether, and one which we do not have time to pursue. Yet I want to end this section by suggesting that the real reason for Barth's insistence upon the full humanity of the biblical text-along with the full humanity of Jesus and that of preaching-was that his particular understanding of the nature of revelation as event drove him to do so.

\section{Revelation and Concealment: an Essential Paradox}

From his earliest writings till his latest, Barth maintains that there is an implicit paradox in the very nature of revelation. God reveals himself, yet he does so in such a way and in such a 
form that in the midst of his revealedness he remains hidden. Thus in the Romans Commentary, citing Kierkegaard and Luther for moral support, Barth writes:

The Gospel requires-faith... It can therefore be neither directly communicated nor directly apprehended... it can appear among us, be received and understood by us, only as contradiction. The Gospel does not expound or recommend itself. It does not negotiate or plead, threaten or make promises. It withdraws itself always when it is not listened to for its own sake... 'Indeed only when that which is believed on is hidden, can it provide an opportunity for faith. And moreover, those things are most deeply hidden which most clearly contradict the obvious experience of the senses' (Luther). ${ }^{15}$

The same precise point undergirds Barth's view of scripture and preaching as developed in the Göttingen Dogmatics and the Church Dogmatics. Thus:

To deny the hiddenness of revelation even in scripture is to deny revelation itself, and with it the Word of God. For God's Word is no longer God's Word when the truth that is new every morning... is made into a sacred reality, when the miracle of God that is encircled with the possibility of offense is made into a marvel to which one may quietly point. ${ }^{16}$

What is being said here, then, is precisely that at the level of the human reality of Jesus, text and sermon these things possess 'no form or comeliness... that we should desire' them, but act as much to veil the reality of God (as that which is truly not God inevitably must) as to reveal him. In the event of revelation God tears the veil away, and makes known the incomprehensible, but as the event is precisely that, something which happens and passes and is gone, the veil itself remains formally in place. For those with 'eyes to see' it becomes transparent, but for others it is and remains utterly opaque.

15Romans (6th ed.; London: OUP, 1933) 39.

16GD I, 59. 
Behind this view of things lies an epistemological and ontological assumption which permeates Barth's theology from the days of his so-called 'dialectical' period through to the very end of the Church Dogmatics. Namely, that God is by definition utterly transcendent, that he can be neither known nor spoken about by human beings as such. He cannot be posited as an object. Put the other way around, human beings are quite incapable of knowing or speaking about God. Thus:

We have to admit that we cannot see, hear, feel, touch or either inwardly or outwardly perceive the one who reveals himself, not because he is invisible or pure spirit, but because he is God, because he is wholly himself, 'I am who I am', the subject that escapes our grasp, our attempt to make him an object. ${ }^{17}$

Again,

God does not belong to the world. Therefore he does not belong to the series of objects for which we have categories and words by means of which we draw the attention of others to them, and bring them into relation with Him. Of God it is impossible to speak, because $\mathrm{He}$ is neither a natural nor a spiritual object. 18

The source of this radical dualism need not concern us at length. In part, at least, it seems to be a response to the somewhat optimistic and imperialistic epistemology of NeoKantian philosophy in which something is known as it is 'objectified' or 'made into an object', that is to say, classified and labelled by the mind in accordance with universally given sets of categories. God, Barth wants to insist (together with Bultmann and others of his generation), cannot be dealt with like that. He cannot be seized and subjected to a confident process of analysis by human reason, put in a box and defined, and thereby effectively tamed. Unlike Bultmann, however, Barth wants equally to insist that this does not mean in the final scheme of things that God is unknowable, that is, restricted

${ }^{17} \mathrm{GD} \mathrm{I}, 136$.

${ }^{18} \mathrm{CD} \mathrm{I} / 2,750$. 
within human experience to some ahistorical, non-cognitive purely moral existential encounter, but rather gives himself to be known precisely in cognitive, verbal, and even fleshlyhistorical terms. 'What if', he asks, 'God be so much God that without ceasing to be God he can also be, and is willing to be, not God as well. What if he were to come down from his unsearchable height and become something different?'19 In this case we must say two things. Firstly, that the form which God assumes in this radical self-objectifying is itself not God. Thus 'what we see, hear, feel, touch, and inwardly and outwardly perceive' (whether it be the man Jesus, the text of scripture or human preaching) 'is always something different, a counterpart, a second thing. ${ }^{\prime 20}$ It is what Barth refers to as the 'secondary objectivity' of God's word. But in, with, and under this creaturely self-objectification, and not apart from it, the Word of God himself may be known:

On this objective condition... revelation is possible. Note that I do not say more than 'possible'. Through the transparency of this concealment... the light of God's revelation can be seen. We cannot take it for granted that it really is seen. This still rests with God. ${ }^{21}$

The veil, in other words, must still be lifted, and lifted by God himself alone. By entering into the realm of human being and knowing in these three forms, the flesh of Christ, the text of scripture, the words of the preacher, the Word of God becomes that which is knowable by us. But in order that he may be known as Word of God, recognised in the midst and in spite of his concealment, this objective, given, humanly recognisable form must be accompanied by the Spirit whose activity 'straddles objectivity and subjectivity' and creates the event, the 'happening' of revelation and faith.

That this happens in spite not only of the creatureliness of the form which the Word assumes but (in the instances of scripture and preaching at least) in spite of its inherent

${ }^{19} \mathrm{GD}$ I, 136.

${ }^{20} \mathrm{GD}$ I, 136.

${ }^{21}$ GD I, 140. 
fallibility and sinfulness, this, Barth insists, is miracle, a miracle of the same sort if not the same magnitude as the creation ex nihilo, the resurrection of Jesus out of the despair of death, and the conception of the embryonic Christ in the virgin's womb. The paradox is the same one in each case.

To return fleetingly, then, to the question of the doctrine of biblical infallibility or inerrancy, Barth's objection to it is that it denies this essential miracle. It cannot bear the paradox, the scandal of the audacious affirmation that weak and errant human words are the very Word of God himself. This identification is too much for it, so in order to cope with it it shifts the scene of the miracle to another place, to an earlier place, positing a miraculous 'preparing of the ground', the furnishing of a sinless and flawless textual humanity for the Word of God to be identified with and incarnate in. As such (the comparison is mine not Barth's) one might say that the logical force of the doctrine is much the same, and posited for the same reasons, as that of the Catholic doctrine of the immaculate conception of Mary. The assumption is that for the Word of God to enter into any genuine union with the human, the human must be purged in advance of its imperfections, since these would be unfitting for God to identify himself or his activity with. Pursuing the same logic it might be asked whether, if our view of preaching were as high as Barth's, we might not be forced to develop some parallel notion in this relation too, some account of how our human verbiage is, prior to being assumed into the task of proclamation, specially purged of its inherent human sinfulness as a necessary condition of its adoption by God as his speech.

For Barth, the scandalon must be allowed to stand, for all the reasons outlined thus far. God's Word comes to us in fully human form. It is veiled from us by this very creatureliness, and becomes 'visible', as it were, only in the event of revelation. The real presence of the Word in human words cannot be guaranteed, coerced, pinned down nor held on to. As in the sacrament, it can only be prayed for and received by faith in, with and under the creaturely elements. There is no magical transubstantiation. As Alan Lewis has written: 
The Eternal Word, by which all things were made, has become fleshly word, exposed to human sight and touch and hearing, exposed, therefore, also to humiliation, hurt and finally to hell. That Word still speaks, of course: a living kerygma which resonates with powerful, transfiguring effect. But it does so strictly as 'the word of the cross', a word of kenosis, of suffering and death, impotence and folly. 22

It is precisely this that provokes the question 'How, in this case, is preaching possible?' It is to Barth's answer to this question that I want to turn very briefly in the next and final section of this paper.

\section{Inspiration as Event: the Word, the Flesh and the Spirit}

Notwithstanding the kenotic aspect of the humanity of the Word, its historically conditioned nature, its contingency, its theological contradictions and limitations, nonetheless, Barth affirms, God's Word is pleased to identify himself with it, to commit himself to it, and, in what can only be described as a miraculous event, to speak through it to human beings. In this event, wrought by Word and Spirit together, the one as the 'objective possibility' of revelation, the other as its 'subjective possibility', these human words actually become the Word of God. God speaks here in such a way that he is heard, as he has spoken here many times before, and promises to do so again and again. As such, both scripture and preaching may be called Word of God in a straightforward and unqualified manner.

But such a description refers not to an attribute which the words possess in and of themselves, nor even one which they come to possess through grace, but precisely to the event in which they are taken up, assumed, and in which God's Word becomes incarnate once again with revealing and redeeming effect. Thus God is himself the subject of this event as well as the object made known, and as we are drawn into it, actively

${ }^{22}$ Alan Lewis, 'Kenosis and Kerygma: the Realism and the Risk of Preaching', in T.A. Hart and D.P. Thimell (eds.), Christ in Our Place (Exeter: Paternoster Press, 1989) 72. 
engaged in knowing, what is in effect taking place is a drawing of us into the very inner heart of God's triune life, into his own self-knowledge, as he posits himself as the Son to be known and loved by the Father in the Holy Spirit. The event of revelation thus has a profoundly trinitarian structure, although in our case it is a trinity rooted firmly in the historical realm: we are drawn to know God as Father in and through our knowing of and sharing in the life of the human Son, the Christos, empowered and sustained by the anointing Spirit. That this miracle should occur, this reconciling and atoning knowing should happen to us or to others is never, of course, within our sphere of influence or responsibility. We are not called upon to conjure it up genie-like, even from a book rather than a bottle: but simply to point away from ourselves to Christ, to bear witness, to tell the story of redemption:

Only God can talk about God. To this extent, in appropriate application of a christological formulation, we might say of preaching as the Word of God that it is 'conceived by the Holy Ghost'.23

Hence we arrive at Barth's understanding of the term 'inspiration' in relation to scripture and its interpretation. There was, he insists, a special activity of the Spirit upon both the prophets and the apostles, commissioning them for their particular task of human witness; and even in the midst of their 'capacity for errors' ${ }^{24}$ Furthermore, God renders the words of scripture theologically reliable so that

...the message which scripture has to give to us, even in its most debatable and less assimilable parts, is in all circumstances truer and more important than the best and most necessary things that we ourselves have said or can say. 25

But the notion of inspiration need not (cannot for reasons which we have rehearsed) be construed in such a way as to involve an

23GD I, 272.

${ }^{24} \mathrm{CD} \mathrm{I} / 2,508$.

${ }^{25} \mathrm{CD}$ I/2, 719. 
inerrant text as such; and nor can it be limited to some past phenomenon resulting in a revelation which is subsequently to be had in codified and textually fossilised form. Rather, 'we have to say that we must view inspiration as a single, timeless-or rather, contemporary act of God... in both the biblical authors and ourselves'. ${ }^{26}$ In this single event of the Spirit, then, the biblical witnesses themselves are in a sense made contemporary with us, and we are given to see and hear what they saw and heard for themselves.

\section{Conclusion}

Real proclamation, therefore, is in essence for Barth

...human talk about God on the basis of the self-objectification of God which is not just there, which cannot be predicted, which does not fit into any plan, which is real only in the freedom of His grace, and in virtue of which $\mathrm{He}$ wills at specific times to be the object of this talk, and is so according to His own good pleasure. ${ }^{27}$

Furthermore,

It must be solely the truth and miracle of God if his Logos, as he does not regard the lowliness of his handmaiden... or view the unclean lips of Isaiah as an obstacle... does not think it impossible to pitch his tent in what is at best our poor and insignificant and stammering talk about God. ${ }^{28}$

The practical implication of this is that we are absolved from every and any attempt to force this event to happen, liberated from the responsibility of generating it, set free from the pressure created by those who, week in and week out, hear and yet do not hear the message. Alan Lewis writes as follows:

The word of the cross itself liberates the community of faith from compulsive, worldly models of success, effectiveness

${ }^{26} \mathrm{GD}$ I, 225.

${ }^{27} \mathrm{CD} \mathrm{I} / 1,92$.

${ }^{28} \mathrm{GD}$ I, 271. 
and power; and her conviction that preaching is the Word of God itself, though anything but antinomian, lifts from the church the crushing burdens of 'relevance' and popularity. Preaching may continue in a culture which humiliates the word, because the riskiness which lays an offensive message on unfashionable messengers reposes firstly and finally in God's own accommodation and commission. ${ }^{29}$

Barth encourages us, therefore, to think of the task of preaching as a human task, to be sure; as a response to the prior word of divine grace, certainly; but much more than this, as that which is possible only on the basis of its objective and subjective conditions, the self-giving of the Son as Jesus Christ, and the presence here and now of the Spirit of Christ at work in the hearts and minds of both preacher and congregation. Jesus Christ is the Proclaimer as well as the proclaimed, and our ministry of proclamation is, therefore, precisely a sharing in his divine and human ministry before the Father through the Spirit, a ministry which for him led via the suffering and rejection of the cross (and only by this route) to resurrection and triumph. It is with this trinitarian perspective firmly in mind that the awesome task of preaching the foolishness of the gospel can be faced with confidence as, each week afresh, we prepare again to embrace the Gethsemane, Calvary and empty tomb which marked the first Friday, Saturday and Sunday morning of the Christian era.

${ }^{29}$ Lewis, op. cit., 88. 